\title{
Urinary Tract Infection and Drug Susceptibility Pattern in Patients of a Medical College Hospital in Bangladesh
}

\author{
Rafiul Alam Khan ${ }^{1}$, Md. Fazlul Karim ${ }^{2}$ \\ Received: February 14, 2013 Accepted: October 16, 2013
}

\begin{abstract}
Background: Urinary tract infection (UTI) is a common and frequently encountered serious morbidity that afflicts the tool not only to all segments of human population but also results in increasing antibiotic resistance due to persistence and mismanagement of the ailment. The present study aimed to ascertain the current situation of antimicrobial resistance of urinary tract infection. Objectives: To find out pyuria by direct microscopy, isolation and identification of the organisms by culture and to know the susceptibility pattern of organisms causing urinary tract infection. Materials and Methods: A total of 180 midstream urine samples were subjected to aerobic bacteriologic culture in the department of Microbiology, Cox's Bazar Medical College and 250-bedded Sadar Hospital, Cox's Bazar during the period of March to October 2012. Specimens were collected from hospitalized and outdoor patients of different age and sex groups. All specimens were examined by routine microscopy to find out significant pyuria ( $\geqslant 5$ pus cells/HPF). Strict aseptic precautions were taken all through the culture system. Results: Out of 180 specimens, 101 (56.11\%) culture yielded significant growth of single organism and $79(43.89 \%)$ yielded no growth. The isolated organisms were E. coli $74.26 \%$, Klebsiella species $12.87 \%$, Enterococci $4.95 \%$, Staphylococcus saprophyticus $3.96 \%$, Pseudomonas species $1.98 \%$ and Proteus species $1.98 \%$. The highest sensitivity was shown by imipenem (100\%) followed by ceftriaxone (65\%), azithromycin (65\%), ciprofloxacin $(60 \%)$ and less sensitive to amoxycillin, cotrimoxazole, cephradine and nalidixic acid ranging 15-30\%. Conclusion: The findings of the present study recommends that UTI should be treated by selective antibiotics obtained from culture and sensitivity test to minimize increasing trend of drug resistance.
\end{abstract}

Key words: Urinary tract infection, Urinary pathogens, Antibiotic susceptibility pattern

J Enam Med Col 2014; 4(1): 21-25

\section{Introduction}

Urinary tract infection (UTI) is one of the most prevalent extraintestinal bacterial infections and it represents one of the most common diseases encountered in medical practice affecting people of all ages. ${ }^{1}$ About 150 million people are diagnosed with UTI each year worldwide. ${ }^{2}$ Most infections are caused by retrograde ascent of bacteria from the fecal flora via the urethra to the bladder and kidney, especially in the females who have a shorter and wide urethra and more readily transfer microorganisms. ${ }^{3}$ Majority of the UTIs are not life threatening and do not cause any irreversible damage. However, when the kidneys are involved, there is a risk of irreparable tissue damage with an increased risk of bacteremia. ${ }^{4}$

UTI could be defined as the persistent presence of actively multiplying microorganisms within the urinary tract. UTI implies both microbial colonization of the urine and invasion of the lower or upper urinary tract by microorganism. ${ }^{5}$ Regarding bacterial etiology of UTI, Escherichia coli is the

1. Assistant Professor, Department of Microbiology, Cox's Bazar Medical College, Cox's Bazar

2. Associate Professor, Department of Microbiology, Kumudini Women's Medical College, Mirzapur, Tangail

Correspondence Rafiul Alam Khan, Phone: 01715-119593 
commonest microorganism both in domiciliary and hospitalized patients. The other common pathogens are species of Klebsiella, Enterococcus, Pseudomonas, Proteus and Staphylococcus saprophyticus. ${ }^{6}$

The incidence of UTI is $20 \%$ greater in women as compared to men due to anatomical position. ${ }^{5}$ Now-a-days, drug resistance is a huge growing problem in treating infectious diseases like malaria, TB, diarrhoea, UTI etc. As suggested by Goldman \& Huskins, the improper and uncontrolled use of antibiotics results in the emergence of antimicrobial resistance, which is a major health problem worldwide. ${ }^{7,8}$ Particularly in the developing world, apart from high level of poverty, ignorance and poor hygiene practices, there is also high availability of fake and spurious drugs. ${ }^{8}$ Studies aimed at gaining knowledge about the type of pathogens responsible for UTI and their susceptibility pattern may help the clinicians to choose the right empirical treatment.

\section{Materials and Methods}

The study was done in the Microbiology department of Cox's Bazar Medical College and 250-bedded Sadar Hospital, Cox's Bazar during the period March to October, 2012. For the purpose of this study 180 clean catch midstream urine (MSU) specimens were collected in sterile container for microscopy, culture and susceptibility test. Each sample was inoculated on both blood agar and MacConkey's agar media and incubated at $37^{\circ} \mathrm{C}$ for $24-48$ hours within 1 hour after collection. Portions of the specimens were centrifuged at $3000 \mathrm{rpm}$ for at least 3 minutes and centrifuged deposits were examined by direct microscopy to find out significant pyuria ( $\geqslant 5$ pus cells/HPF). Specimens showing growth were subjected for colony count according to standard method. ${ }^{9}$ Colony count $\geqslant 1 \times 10^{5} / \mathrm{mL}$ of urine was considered as significant. The isolated bacteria were identified accordingly by colony morphology, Gram's staining, motility, appropriate biochemical test and direct agglutination test using known specific antisera. Antibiotic susceptibility tests were carried out on MuellerHinton agar plate by disk diffusion method. Commercially available antibiotic discs were used. After overnight incubation, zones of inhibition were measured in $\mathrm{mm}$ and results were reported as sensitive and resistant as per standard chart.

\section{Results}

Out of 180 cases, 60 were in the age group of up to 12 years where $24(40 \%)$ were male and $36(60 \%)$ were female. Out of 120 cases in the age group of above 12 years $54(45 \%)$ and $66(55 \%)$ were male and female respectively. Total male were $78(43.33 \%)$ and female were $102(56.67 \%)$ giving a male to female ratio $1: 1.3$ (Table I).

Table I: Age and sex distribution of study population

\begin{tabular}{|l|c|c|}
\multicolumn{1}{|c|}{ Age group } & Male & Female \\
\hline Up to 12 years $(\mathrm{n}=60)$ & $24(40 \%)$ & $36(60 \%)$ \\
\hline Above 12 years $(\mathrm{n}=120)$ & $54(45 \%)$ & $66(55 \%)$ \\
Total 180 & $78(43.33 \%)$ & $102(56.67 \%)$ \\
\hline
\end{tabular}

Table II shows the comparison between microscopic findings and culture results of 180 urine specimens in different age and sex groups. In both age groups females were predominating regarding pyuria and growth in culture. Out of 24 specimens six (25\%) from male in the age group of up to 12 years showed significant pyuria of which five $(20.83 \%)$ showed growth in culture. Corresponding values for female in same age group was $18(50 \%)$ and $10(27.78 \%)$ respectively. In the age group above 12 years, the values for significant pyuria and culture positivity in male were $45(83.33 \%)$ and $42(77.78 \%)$ and in female were $50(75.75 \%)$ and $44(66.67 \%)$ respectively.

Table II: Comparison of findings between direct microscopy and culture result

\begin{tabular}{|l|c|c|}
\hline Age groups & $\begin{array}{c}\text { Direct microscopy } \\
(\geqslant 5 \text { pus cells/HPF })\end{array}$ & $\begin{array}{c}\text { Culture positive colony } \\
\text { count }(\geqslant 1 \times 105 / \mathrm{mL})\end{array}$ \\
\hline $\begin{array}{l}\text { Up to } \mathbf{1 2} \text { yrs of age } \\
\text { (n=60) }\end{array}$ & & \\
\hline $\begin{array}{l}\text { Male }(\mathrm{n}=24) \\
\text { Female }(\mathrm{n}=36)\end{array}$ & $06(25 \%)$ & $05(20.83 \%)$ \\
\hline $\begin{array}{l}\text { Above } \mathbf{1 2} \text { yrs of age } \\
(\boldsymbol{n}=\mathbf{1 2 0})\end{array}$ & $18(50 \%)$ & $10(27.78 \%)$ \\
\hline $\begin{array}{l}\text { Male }(\mathrm{n}=54) \\
\text { Female }(\mathrm{n}=66)\end{array}$ & $45(83.33 \%)$ & $42(77.78 \%)$ \\
Total $(180)$ & $50(75.76 \%)$ & $44(66.67 \%)$ \\
& $119(66.11 \%)$ & $101(56.11 \%)$ \\
\hline
\end{tabular}


Of the 180 urine samples evaluated, a total 101 (56.11\%) culture yielded significant growth of single organism and $79(43.89 \%)$ yielded no growth. Out of these 101 isolates, E.coli was found as leading agent 75 (74.26\%) followed by Klebsiella species 13 (12.87\%), Enterococci species 5 (4.95\%), Staph. saprophyticus 4 (3.96\%), Pseudomonas species $2(1.98 \%)$ and Proteus species 2 $(1.98 \%)$ (Table III).

Table III: Bacteria isolated form UTI patients $(\mathrm{n}=101)$

\begin{tabular}{|l|c|c|}
\hline Isolated bacteria & Number of cases & Percentage \\
\hline E. coli & 75 & 74.26 \\
\hline Klebsiella species & 13 & 12.87 \\
\hline Enterococci species & 5 & 4.95 \\
\hline Staph. saprophyticus & 4 & 3.96 \\
\hline Pseudomonas species & 2 & 1.98 \\
Proteus species & 2 & 1.98 \\
Total & 101 & 100 \\
\hline
\end{tabular}

Susceptibility pattern of individual organism is shown in Table IV. We find 100\% sensitivity for imipenem in all six groups of bacterial isolates. Resistance for cotrimoxazole was highest (82.67\%) for E.coli, $76.92 \%$ for Klebsiella, $80 \%$ for Enterococci, $75 \%$ for Staph. saprophyticus, $100 \%$ for Pseudomonas and Proteus. Resistance for amoxycillin was $80 \%$ for E.coli, $76.92 \%$ for Klebsiella, $80 \%$ for Enterococci, $75 \%$ for Staph. saprophyticus, $100 \%$ for Pseudomonas and Proteus. Sensitivity for ciprofloxacin, ceftriaxone, azithromycin ranked higher than amoxycillin, cotrimoxazole, cephradine and nalidixic acid. All the organisms were found $100 \%$ susceptible to imipenem.

Table IV: Antibiotic susceptibility pattern of isolated uropathogens

\begin{tabular}{|c|c|c|c|c|c|c|c|}
\hline $\begin{array}{l}\text { Antimicrobial } \\
\text { agents }\end{array}$ & $\begin{array}{l}\text { Susceptibility } \\
\text { pattern }\end{array}$ & $\begin{array}{c}\text { E. coli } \\
\text { Number }(\%)\end{array}$ & $\begin{array}{l}\text { Klebsiella } \\
\text { Number (\%) }\end{array}$ & $\begin{array}{l}\text { Enterococci } \\
\text { Number (\%) }\end{array}$ & $\begin{array}{l}\text { S saprophyticus } \\
\text { Number (\%) }\end{array}$ & $\begin{array}{l}\text { Pseudomonas } \\
\text { Number (\%) }\end{array}$ & $\begin{array}{c}\text { Proteus } \\
\text { Number (\%) }\end{array}$ \\
\hline \multirow[t]{2}{*}{ Amoxycillin } & $\mathrm{S}$ & $15(20)$ & $3(23.08)$ & $1(20)$ & $1(25)$ & 0 & 0 \\
\hline & $\mathrm{R}$ & $60(80)$ & $10(76.92)$ & $4(80)$ & $3(75)$ & $2(100)$ & $2(100)$ \\
\hline \multirow[t]{2}{*}{ Cotrimoxazole } & $\mathrm{S}$ & $13(17.33)$ & $3(23.08)$ & $1(20)$ & $1(25)$ & 0 & 0 \\
\hline & $\mathrm{R}$ & $62(82.67)$ & $10(76.92)$ & $4(80)$ & $3(75)$ & $2(100)$ & $2(100)$ \\
\hline \multirow[t]{2}{*}{ Cephradine } & S & $19(25.33)$ & $4(30.77)$ & $2(40)$ & $2(50)$ & 0 & 0 \\
\hline & $\mathrm{R}$ & $56(74.67)$ & $9(69.23)$ & $3(60)$ & $2(50)$ & $2(100)$ & $2(100)$ \\
\hline \multirow[t]{2}{*}{ Nalidixic acid } & S & $23(30.67)$ & $3(23.08)$ & $2(40)$ & $2(50)$ & $1(50)$ & $1(50)$ \\
\hline & $\mathrm{R}$ & $52(69.33)$ & $10(76.92)$ & $3(60)$ & $2(50)$ & $1(50)$ & $1(50)$ \\
\hline \multirow[t]{2}{*}{ Ceftriaxone } & S & $49(65.33)$ & $8(61.54)$ & $3(60)$ & $2(50)$ & $1(50)$ & $1(50)$ \\
\hline & $\mathrm{R}$ & $26(34.67)$ & $5(38.46)$ & $2(40)$ & $2(50)$ & $1(50)$ & $1(50)$ \\
\hline \multirow[t]{2}{*}{ Azithromycin } & S & $45(60)$ & $9(69.23)$ & $3(60)$ & $3(75)$ & $1(50)$ & $2(100)$ \\
\hline & $\mathrm{R}$ & $30(40)$ & $4(30.77)$ & $2(40)$ & $1(25)$ & $1(50)$ & 0 \\
\hline \multirow[t]{2}{*}{ Ciprofloxacin } & S & $50(66.67)$ & $8(61.54)$ & $4(80)$ & $3(75)$ & $2(100)$ & $2(100)$ \\
\hline & $\mathrm{R}$ & $25(33.33)$ & $5(38.46)$ & $1(20)$ & $1(25)$ & 0 & 0 \\
\hline \multirow[t]{2}{*}{ Imipenem } & S & $75(100)$ & $13(100)$ & $5(100)$ & $4(100)$ & $2(100)$ & $2(100)$ \\
\hline & $\mathrm{R}$ & 0 & 0 & 0 & 0 & 0 & 0 \\
\hline
\end{tabular}




\section{Discussion}

Antibiotic resistance of bacteria has been gradually becoming a major medical and public health problem. Injudicious use of antibiotics has resulted in emergence of many Gram positive and Gram negative resistant bacterial population. In this study $60(33.33 \%$ ) samples were from children (up to 12 years) and rest were from above 12 years age group. Female were predominating in both age group indicating that UTI is common in women which was supported by many authors. ${ }^{6}$ In this study significant pyuria and culture positivity was also higher in females. It is evident that E. coli was the predominant uropathogens $(74.26 \%)$ causing UTI followed by Klebsiella species (12.87\%), Enterococci species (4.95\%), Staphylococcus saprophyticus (3.96\%), Pseudomonas species (1.98\%) and Proteus species (1.98\%). Staphy-lococcus saprophyticus, Pseudomonas species and Proteus species were also the less frequent agents causing UTI in another study. ${ }^{10}$ The percentage of resistance of E. coli to the antimicrobial agents were $82.67 \%$ to cotrimoxazole, $80 \%$ to amoxycillin, $74.67 \%$ to cephradine and $69.33 \%$ to nalidixic acid. The percentages of resistance of pathogens varied between $100 \%$ and $20 \%$ to antimicrobial agents while susceptibility of the pathogens varied between $100 \%$ and $17.33 \%$. In this study, all types of bacterial isolates were $100 \%$ susceptible to imipenem. A significant increase in resistance of pathogenic strains to cotrimoxazole, amoxycillin, nalidixic acid and cephradine has been found worldwide. ${ }^{11}$ The overall rate of resistance to cotrimoxazole found in this study was significantly higher than those reported by others. ${ }^{12}$ For the past decades, cotrimoxazole or trimethoprim alone has been used widely as an empirical therapy for UTI caused by E. coli. The results of this study indicate that ciprofloxacin resistance was slightly higher than that reported in previous studies. ${ }^{13}$ A decline in the activity of ciprofloxacin would be especially problematic in view of the ability of Gram negative bacilli to acquire resistance to all other classes of antimicrobials. ${ }^{14}$ Our study shows that resistance to ciprofloxacin continues to increase. If urgent measures are not taken to control the situation, we may see the return of the era of the search for new drugs to fight bacterial infections. According to Mandal et al ${ }^{15} \mathrm{E}$. coli was the commonest cause of
UTI and antibiotic resistance was high among the strains. The practices of self medication, drug abuse and indiscriminate use of antibiotics among the general population certainly will favor the emergence and propagation of resistant strains in future.

\section{Acknowledgment}

We are grateful to the clinicians who sent patients for this study and to technologists working in Microbiology department of Cox's Bazar Medical College for their technical cooperation.

\section{References}

1. Kunin CM. Urinary tract infections in females. Clin. Infect. Dis. 1994; 18: 1-12.

2. Gupta K. Increasing antimicrobial resistance and the management of uncomplicated community acquired urinary tract infections. Int. J. Antimicrobial Agents. 2001; 135: 41-50.

3. Jones RN, Inabo HI, Abanili HBI. Antimicrobial susceptibility of some urinary tract clinical isolates to commonly used antibiotics. Afr. J. Biotechnol. 2006; 5(5): 487-489.

4. Hvidberg H, Struve C, Krogfelt KA, Christensen N, Rasmussen SN, Frimodt-Moller M. Development of a long-term ascending urinary tract infection mouse model for antibiotic treatment studies. Antimicrob. Agents Chemother. 2000; 44(1): 156-163.

5. Banu K, Khan J, Rifat, Begum H, Munir S, Akber N et al. Patterns of antibiotic sensitivity of bacterial pathogens among urinary tract infection (UTI) patients in a Pakistani population. African Journal of Microbiology Research 2012; 6(2): 414-420.

6. Haque MN, Shamsuzzaman AKM, Khatun M, Khan RA, Akter S, Rahman A. Antibiotic sensitivity pattern of bacterial isolates causing urinary tract infection. Sir Salimullah Medical College J. 1998; 6(1): 5-12

7. Goldman DA, Huskins WC. Control of nosocomial antimicrobial resistant bacteria: a strategy priority for hospitals worldwide. Clin. Infec. Dis. 1997; 24: 139-145.

8. Kandan SM, Ganesapandian S, Singh M, Kumaragura AK. Antimicrobial susceptibility pattern of pathogenic bacteria causing human urinary tract infection. Asian Journal of Medical Sciences 2011; 3(2): 56-60.

9. Cheesbrough M. In: Medical laboratory manual for tropical countries (Vol II). Oxford: Butterworth Heinemann Ltd., 1984: 155-156, 205. 
10. Goswami R, Bal CS, Tejaswi S, Punjabi GV, Kochupillai $\mathrm{N}$. Prevalence of urinary tract infection and rural scars in patients with diabetes mellitus. Diabetes Res. Clin. Pract. 2001; 53(3): 181-186.

11. Hooton TM. Fluoroquinolones and resistance in the treatment of uncomplicated urinary tract infection. Int. J. Antimicrob. Agents. 2003; 22: 565-572.

12. Valdivieso F, Trucco O, Prado V, Diaz MC, Ojeda A. Antimicrobial resistance agents causing urinary tract infections in 11 Chilean hospitals [PRONARES Project]. Rev Med Chil 1999; 127(9): 1033-1040.

13. Sahm DF, Thornsberry C, Mayfield DC, Jones ME, Karlowsky JA. Multidrug-resistant urinary tract isolates of Escherichia coli: prevalence and patients demographics in the United States in 2000. Antimicrob. Agents Chemother. 2001; 45: 1402-1406.

14. Sahm DF, Critchley IA, Kelly LJ, Karlowsky JA, Macfield DC, Thornsberry $\mathrm{C}$ et al. Evaluation of current activities of fluoroquinolones against Gram negative bacilli centralized in vitro testing \& electronic surveillance. Antimicrob. Agents Chemother. 2001; 45(1): 267-274.

15. Mandal P, Kapil A, Goswami K, Das B, Dwivedi SN. Uropathogenic Escherichia coli causing urinary tract infections. Indian J. Med. Res. 2001; 114: 207-211. 